\title{
Tropical Fruit Growers' Water Use and Conservation Practices in Miami-Dade County 1
}

\author{
Rafael Muñoz-Carpena, Jonathan H. Crane, Glenn D. Israel, and Carlos F. Balerdi²
}

\section{Introduction and background}

The Miami-Dade County tropical fruit crops industry employs over 2,100 people and has at least a $\$ 137$ million impact on the state economy (Degner et al., 2002a; Degner et al., 2002b). There are about 15,611 acres of fruit production in Miami-Dade County and about 1,200 acres in other south Florida counties. The estimated number of fruit producers in Miami-Dade County ranges from about 265 to 823 depending upon the criteria and sources used to estimate it (Degner et al., 2002b; J. Crane and C. Balerdi, personal communication). In general, over $82 \%$ of the farms in Miami-Dade County have irrigation systems, representing about $85 \%$ of the agricultural land in production (Degner et al., 2002b).

The major issues facing the tropical fruit crops industry in Florida include: marketing and foreign competition, land use planning, pests and diseases, water and fertilizer management, natural disaster avoidance and mitigation, and sustainable cultural practices. Due to the on-going Everglades and Biscayne National Park restoration projects, water and fertilizer management practices for the tropical fruit industry has become a critical component of the sustainability of this industry.

Water use, management, and quality are major issues in Florida's Miami-Dade County where periods of excessive rainfall (flooding) and extended dry spells (drought) are experienced occasionally. Agricultural practices (e.g., irrigation and fertilizer management) potentially affect the water quality of the Biscayne Aquifer and Biscayne Bay. A previous irrigation management survey of tropical fruit producers in Miami-Dade County reported about $60 \%$ used low volume irrigation systems in their orchards (Li et al., 2000). In these orchards, irrigation scheduling was based mostly on the amount and frequency of rainfall (73\%) and only $15 \%$ on soil moisture monitoring. However, water conservation practices of the Miami-Dade County tropical fruit industry are largely undocumented.

This fact sheet reports water conservation trends for tropical fruit producers based on a recent extensive survey carried out in Miami-Dade County.

1. This document is Fact Sheet ABE345, one of a series of the Agricultural and Biological Engineering Department, Florida Cooperative Extension Service, Institute of Food and Agricultural Sciences, University of Florida. Published December 2003. Please visit the EDIS web site at http://edis.ifas.ufl.edu.

2. R. Muñoz-Carpena, Asst. Prof., Hydrologist, and J.H. Crane, Prof., Tropical Fruit Crop Specialist, Tropical Research and Education Center, Homestead, FL; G.D. Israel, Prof., Extn. Prog. Development, Agricultural Education and Communication Dept., Gainesville, FL; C.F. Balerdi, Multi-County Tropical Fruit Crops Extension Agent, Miami-Dade County Cooperative Extension Service, Homestead, FL; Cooperative Extension Service, Institute of Food and Agricultural Sciences, University of Florida, Gainesville,

The Institute of Food and Agricultural Sciences is an equal opportunity/affirmative action employer authorized to provide research, educational information and other services only to individuals and institutions that function without regard to race, color, sex, age, handicap, or national origin. For information on obtaining other extension publications, contact your county Cooperative Extension Service office. Florida Cooperative Extension Service/Institute of Food and Agricultural Sciences/University of Florida/Christine Taylor Waddill, Dean. 


\section{Survey and analysis methodology}

The survey involved a random sample of 208 of the 265 commercial fruit producers that were identified from the mailing lists obtained from the Miami-Dade County/IFAS Cooperative Extension Service and other growers' organizations in Miami-Dade County. The survey recipients were selected according to the size of their operation to ensure representation across all tropical fruit growers. The number of surveys sent out represents from $25 \%$ to $79 \%$ of the commercial tropical fruit growers (depending on source accepted for the total number of operations in the County).

The survey instrument contained questions concerning water consumption and irrigation practices, motivations for their adoption by growers, issues affecting water use, drought and flooding experience, and water management. Questions related to when the grower first started farming, and size of the farm were added to gain a perspective of changes in the area with time.

The survey procedures were tailored to maximize growers' participation (Dillman, 2000). Each potential respondent received a letter informing him or her of the purpose of the survey. Two weeks later the surveys were sent out, and telephone follow up was done 4 and 8 weeks later. The survey protocol was designed to collect enough responses for statistical analysis of the influence of the economic, technical, and sociological factors on water conservation practices in the area. The survey data were analyzed using SAS software FREQ and MEANS statistical procedures (SAS, 1999).

\section{Survey results}

\section{Background}

Although an initial random sample of 243 surveys was sent out, some could not be contacted or were no longer in business. Of the 208 growers who were in the reachable sample, 85 returned usable surveys. The survey response rate was $41 \%$, representing $25 \%$ of the fruit crops acreage and nearly one-third of the estimated number of commercial fruit growers. Mail-back survey response rates of 10 to $50 \%$ are common, and typically may be as low as 20\% (Donan et al., 2000; Nachmias and Nachmias, 1976; Neuman, 1997), so the response rate from this survey is considered satisfactory.

The mean orchard size for respondents was 48 acres, which is similar to that found in the area in a recent agricultural economic study (Degner et al., 2001a; 2001b). Land was about evenly distributed among those producers, who owned (34\%), leased $(30 \%)$, or managed $(36 \%)$ orchards on someone else's property. Nearly all the fruit orchards are irrigated (96\%) which is to be expected because irrigation is the main method of cold protection during occasional freezing events (Crane, personal communication). Those producers that responded to the survey had an average of 20 years in farming.

\section{Changes in irrigation technology}

There have been dramatic changes in irrigation system technology and soil water content monitoring during the past 20 years. Generally, irrigation efficiencies have been improved in agricultural operations by more direct water delivery systems that limit the application rate and land surface area irrigated (e.g., drip, microsprinkler) and by the use of soil water content monitoring devices (e.g., tensiometers, capacitance probes) that enable producers to reduce leaching and apply water based solely on crop needs.

Nearly two-thirds of the fruit producers reported having a high volume irrigation system (e.g., high volume overhead, high volume under tree, high volume in-tree) when their operations first started and currently (Fig. 1). A high volume system applies 0.20 inches water acre ${ }^{-1}$ hour $^{-1}$ or more usually using a diesel engine pump. The main purpose of high volume systems is to protect trees during freezing events. This is highly recommended as freeze tolerance of subtropical and tropical fruit trees is limited (Schaffer and Andersen, 1994).

The use of rotating water cannons (also called "big guns") for irrigation has decreased by about $50 \%$ (Fig. 1). This is due to the loss of 'Tahiti' lime acreage and replacement of big gun irrigation with other high volume or more efficient irrigation systems. Big gun irrigation is a high volume system 


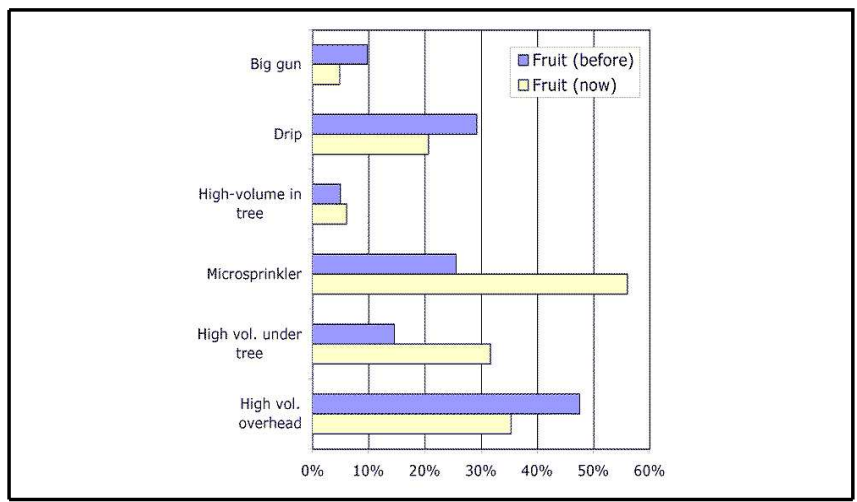

Figure 1. Changes in irrigation systems used by fruit producers with time. The term "before" denotes the irrigation system used when the grower first started farming and "after" denotes the current irrigation system used.

but the water distribution and application timing is not appropriate for freeze protection.

About $30 \%$ of the fruit producers reported using low volume irrigation when they first started their operations (Fig. 1). However, over $75 \%$ of the producers reported that they now use these systems. The slight decline in drip irrigation use and the doubling of microsprinkler use reflects a shift to low volume irrigation systems that distribute water over a larger area than drip systems. Low volume systems are more water- and energy-efficient and have the capability of applying liquid fertilizers, which may save time, labor, energy, and fertilizer. They are recommended for the extremely coarse (gravelly-loam) "rock-plowed" soils in the area. These soils have limited water holding capacity and extreme permeability.

\section{Water sources}

The use of open, uncased wells has declined by $7.3 \%$ in fruit crop operations (Fig. 2). In contrast, the use of capped, cased wells has increased from $50 \%$ before to $54 \%$ now. The increased use of capped, cased wells for fruit crop operations reflects the relatively permanent location of irrigation wells in these types of operations.

\section{Flooding and drought frequency}

Over $27 \%$ of the respondents have experienced flooding within the last five years. Of those operations reporting flooding, 59\% reported a yield decline and $58 \%$ a fruit quality reduction in their

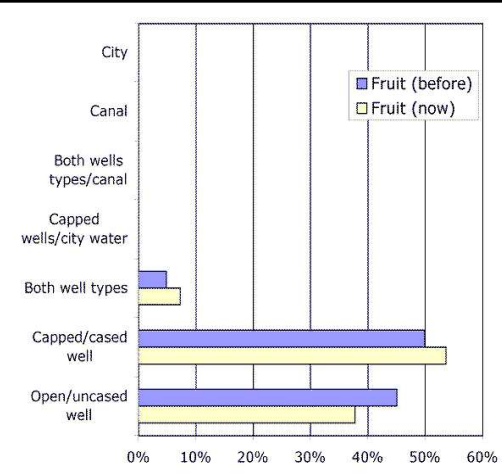

Figure 2. Changes in water sources used by fruit producers with time. The term "before" denotes the source of water used when the grower first started farming and "after" denotes the current water source used for irrigation.

commodity as a result of flooding. About $23 \%$ of the fruit operations experienced drought conditions within the last 5 years. Of those reporting drought, about $30 \%$ had a reduction in yield and $35 \%$ a reduction in commodity quality.

\section{Water conservation practices, and the motivations for adopting them}

The survey included questions on the adoption of practical water conservation practices (e.g., installation of low volume irrigation systems, monitoring soil water content, irrigating at night, etc.). When designed and used properly, microirrigation systems (e.g., drip, microsprinkler) conserve water.

About $21 \%$ of the fruit producers reported they currently grow drought tolerant fruit crops with another $7 \%$ indicating they plan to in the future. About $37 \%$ and $55 \%$ of the fruit operations reported they used a drip or microsprinkler irrigation system in at least part of their operations, respectively. Another $17 \%$ and $9.5 \%$ plan on installing drip and microsprinkler irrigation systems in the future, respectively. Only about $10 \%$ of those surveyed currently use water meters to monitor water usage but another $20 \%$ indicated they plan to do so in the future.

About $49 \%$ of the fruit producers reported using some type of soil moisture monitoring, and another $19 \%$ plan to do so in the future. Of that $49 \%$ monitoring soil water content, $45 \%$ monitor by inspecting and feeling the soil, $33 \%$ use tensiometers 
and the rest use other measurement devices (e.g., gypsum blocks, capacitance probes). Fifty percent of those surveyed said they used water saving devices (timers, automatic shutoff valves, rain switches, etc.) and another $13 \%$ indicated they planned to do so in the future.

Nearly $60 \%$ of the producers monitored weather data, and about two-thirds (64\%) monitored rainfall as part of their irrigation decision-making process. Most monitor rainfall through the National Weather Service $(26 \%)$, and/or by on-farm rain gauges $(20 \%)$ or weather stations (10\%). Nearly $43 \%$ and $19 \%$ monitored, or plan to monitor, plant growth stages as part of their irrigation management process, respectively. Eighty-three percent of those surveyed irrigated mainly at night or late evening, or early morning to reduce evaporative losses and distortion of the irrigation pattern. Slightly over 53\% of the fruit producers indicated they currently used mulch, and another $23 \%$ intend to in the future.

Close to one quarter (24\%) of the fruit operations kept irrigation records and another 18\% planned to in the future. About $30 \%$ and $43 \%$ of the producers have used and plan to use the services of the South Dade Soil and Water Conservation District's Mobile Irrigation Laboratory (MIL), respectively. This service is designed to assess the water and energy use efficiency of irrigation systems at no charge to producers. Recommendations for repairs and/or upgrades are provided in an effort to increase irrigation efficiency, and conserve water.

Although at present there is no major source of urban recycled water (waste water) in south Florida, $45 \%$ of the fruit producers surveyed indicated that they are interested in using this irrigation source in the future. For this practice to be implemented on a wider basis an extensive state and local government commitment would be required to establish and maintain suitable water recycling facilities in the south Florida region.

The three most common reasons for practicing water conservation include water, time, and money savings. For tropical fruit producers, the most consistent reasons given were water savings, followed by money savings. For example, saving water was cited as the primary reason for using drip irrigation, growing drought tolerant fruit crop species, irrigating at night or early morning or late evening, using recycled water, measuring rainfall, monitoring the weather, and utilizing the services of the MIL. Water and money savings were of equal importance in utilizing microsprinkler irrigation, mulch, installing water saving devices, and monitoring soil water content and plant growth. Saving time was cited as the most important reason for keeping irrigation records.

\section{Conclusions and challenges ahead}

Our results generally show an increase in the adoption of water conservation practices among tropical fruit growers in the last 20 years. For the most part, tropical fruit operations have adopted low volume irrigation systems and irrigation scheduling technologies from a moderate to a large extent. Over $20 \%$ of the respondents reported periodic flooding and drought, with a reduction in yield and product quality reported by over one-third to one-half of these respondents. The main reason for adoption of water conservation practices varied although the most consistently given reason was water savings.

In spite of these positive findings, there remain important educational challenges to optimize water use while protecting the environment (Muñoz-Carpena et al., 2003). Improvements are needed in four major areas:

1. Water delivery systems including the phase out of high volume big-guns and improvements in low volume irrigation systems.

2. Improvement in water management practices including record keeping, use of soil water content monitoring, irrigation system maintenance, and periodic irrigation evaluation by the Mobile Irrigation Lab.

3. Protection of water sources by increased use of capped and cased wells.

4. Development of a "Tropical Fruit Growers BMP Manual" integrating improved water management with plant nutrition and IPM. 


\section{Literature cited}

Degner, R.L., T.J. Stevens, and K.L. Morgan.

2002a. Miami-Dade County Agricultural Land

Retention Study, Summary and Recommendations, Vol. 1. Fla. Agri. Market Res. Center, IFAS, University of Florida, Gainesville, Fla. p. 89.

Degner, R.L., T.J. Stevens, and K.L. Morgan. 2002b. Miami-Dade County Agricultural Land Retention Study, Appendix B, Vol. 3. Fla. Agri. Market Res. Center, IFAS, University of Florida, Gainesville, Fla. p. 201.

Dillman, D.A. 2000. Mail and Internet Surveys: The Tailored Design Method. J. Wiley and Sons, New York.

Donan, A.H., R. Kreutzwiser, and R. de Loë. 2000. Rural water use and conservation in southwestern Ontario. J. Soil and Water Conservation 55:161-171.

Li, Y., J.H. Crane, B. Boman, C. Balerdi. 2000. Irrigation management survey for tropical fruit crops in south Florida. Proc. Fla. State Hort. Soc.

113:40-42.

Muñoz-Carpena, R., J. H. Crane, G.D. Israel and C. Yugalevitch. 2003. Water Conservation Survey of Miami-Dade County Agricultural and Golf Course Commercial Water Users. Proc. Fla. State Hort. Soc.

116:in press.

Nachmias D. and C. Nachmias. 1976. Research Methods in the Social Sciences. St. Martins Press, New York.

Neuman, L.W. 1997. Social Research Methods: Qualitative and Quantitative Approaches. ${ }^{\text {rd }}$ ed. Allyn and Bacon Publ., Boston.

SAS Institute Inc. (1999). SAS 8.01 [Computer software]. Cary, NC: SAS Institute Inc.

Schaffer, B. and P.C. Andersen. 1994. Handbook of environmental physiology of fruit crops, Vol. II: sub-tropical and tropical crops. CRC Press, Inc., Boca Raton, Fla. P. 310. 